\title{
THE IMPORTANCE OF DOCUMENTING INDIGENOUS AFRICAN SHEET MUSIC
}

\author{
N. Netshivhambe Evans \\ Music Department, University of Pretoria
}

Email: evans.netshivhambe@up.ac.za

\begin{abstract}
As informal communities become villages, villages become townships and townships become cities. The importance of living in a structured society with better social services becomes a priority in many communities. Living in a society that has improved road infrastructures, accessible hospitals, and affordable education for citizens has become a key part of modern life. However, the more advanced societies become, the less indigenous cultural heritage knowledge a society consumes. Indigenous African music heritage becomes irrelevant in changing societies, and it becomes a victim of changing societies by default. Education systems from basic to advanced level are moving with global trends and there is no space for indigenous cultural knowledge. There is no interest to study such knowledge, particularly from the younger generation. As people migrate from rural to urban settlements in search of jobs and a better life, indigenous African music heritage is less practiced by many communities. Urbanisation makes indigenous music heritage look less formal to its own people, due to social changes. Communities that practise indigenous music heritage become fewer and fewer as urbanisation takes precedence in many societies. Documenting indigenous African sheet music for teaching and learning it is the best way to preserve such diminishing heritage practice.
\end{abstract}

Keywords: Sheet music; indigenous knowledge; African music; music heritage

\section{Introduction}

Future generations in African communities are faced with the generational problem of indigenous music heritage becoming extinct in the society if nothing is done about the problem of not documenting indigenous African sheet music. This chapter discusses socio-cultural challenges with which indigenous African music heritage is faced in today's modern world. The paper will interrogate such challenges by looking at indigenous African music transcription as an alternative solution to the preservation and documentation of African sheet music for future generations.

For an African to re-produce his/her own collective knowledge as an insider it can be a vital contribution to the development of new indigenous information for teaching purposes. Africans have always been known to be keepers of indigenous knowledge systems and heritage. This can be a significant contribution towards formulating a "decolonised education" at institutions of higher learning. Indigenous African knowledge is a magnet for many researchers, which is proof that there is much to be discovered and used as African currency. For decades African Indigenous knowledge has been the resonant force that has kept Africans largely united and unique from other nations. The unfortunate part is that very little is documented about such data. The academic project has stimulated many research enquiries into fields of Indigenous African knowledge I believe there is much that can be done in preserving and promoting Indigenous knowledge systems through documenting information using current technology and professional methods.

The impetus for preserving and documenting African indigenous knowledge, particularly in African music heritage is the on-going scholarship and discourse. The indigenous African music heritage preservation and documentation has been growing in leaps and bounds in spite of proper structures being in place. The aural preservation methodology has always been the manner that Africans have used to transfer knowledge from one 
generation to another. This has its own disadvantages as it has so far proven not to be the best method of preserving knowledge. The best preservation of knowledge that has been used by the Western and European researchers of documenting knowledge has proven to be the leading method of knowledge preservation. Africans have woken up to the realisation that, had this been a method they could apply, more documentation would have been preserved and improved on as well as being usable for educational purposes. There needs to be a professional documentation strategy as a way to protect the rich heritage of indigenous African music that seems to be under the threat of extinction.

Many South African academic institutions are faced with the challenge of addressing the present "colonised education" and this on-going discourse is to address the imbalances of the past. Indigenous African music heritage is at the centre of "decolonised education" in the sense that it transcends educational knowledge that has only existed in an aural format, as created by the practitioners. Many prolific indigenous African music practitioners have advocated for indigenous African knowledge to be professionalized; but with no success due to the lack of proper structures and a deeper understanding of how indigenous music heritage should be taught as a subject at the higher education level. Navigating the terrain of indigenous cultural music heritage, music practitioners and cultural activists have attempted to improve the picture with examples of how indigenous instruments and songs could be used as a teaching model at a higher education level.

At the height of the struggle for its survival, the indigenous African music knowledge system has emerged as a persistent tool for education and heritage preservation. This paper discusses socio-cultural challenges with which indigenous music heritage is faced with in today's modern world. By creating a body of African music repertory, the gap between Western and African music education can slowly be closed. Students who are aspiring to pursue African music studies can have a broader selection of instruments to study and master while having access to the existing African music repertory. This will also help to sustain certain branches of cultural and heritage studies, thus enhancing the profile of indigenous music. The motivation for this paper was stimulated by the significant void in the availability of indigenous sheet music records in universities, as well as the dearth of South African heritage sheet music archives available for teaching purposes.

The methodology used for this research was based on the available collection of indigenous African sheet music that is accessible from one of the biggest sheet music archives called South African Music Rights Organization (SAMRO), including availability of such sheet music in some of the South African university libraries. The SAMRO archive collection is the biggest source of sheet music collection reference that many organisations and institutions of higher learning use to find sheet music. In 2015 the SAMRO archive contacted all South African universities in their music departments, as part of a preliminary test for a transcription feasibility study. This was an attempt to initiate a transcription project that could lead to more and more indigenous African cultural music being transcribed. The response was disappointing; the few universities that did respond did not want to pursue the initiative. This was a clear indication that it is difficult for formal institutions such as universities (who have the resources to champion these kinds of preservation efforts) to implement such initiatives. It is even more difficult for a non-profit organisation, such as SAMRO to take on the role that government should be doing or at least government-supported institutions should be taking part on, to try and advance the preservation of indigenous African music sheet collection for educational purposes.

In the process of writing this paper, I kept recalling a story about a man I encountered growing up. The man was given a nick name called Thoho ndi Dendele, because of the instrument he used to play. It is the story of an indigenous artist determined to do whatever it takes to get recognition in the community. This man played an indigenous instrument called a Dende. 


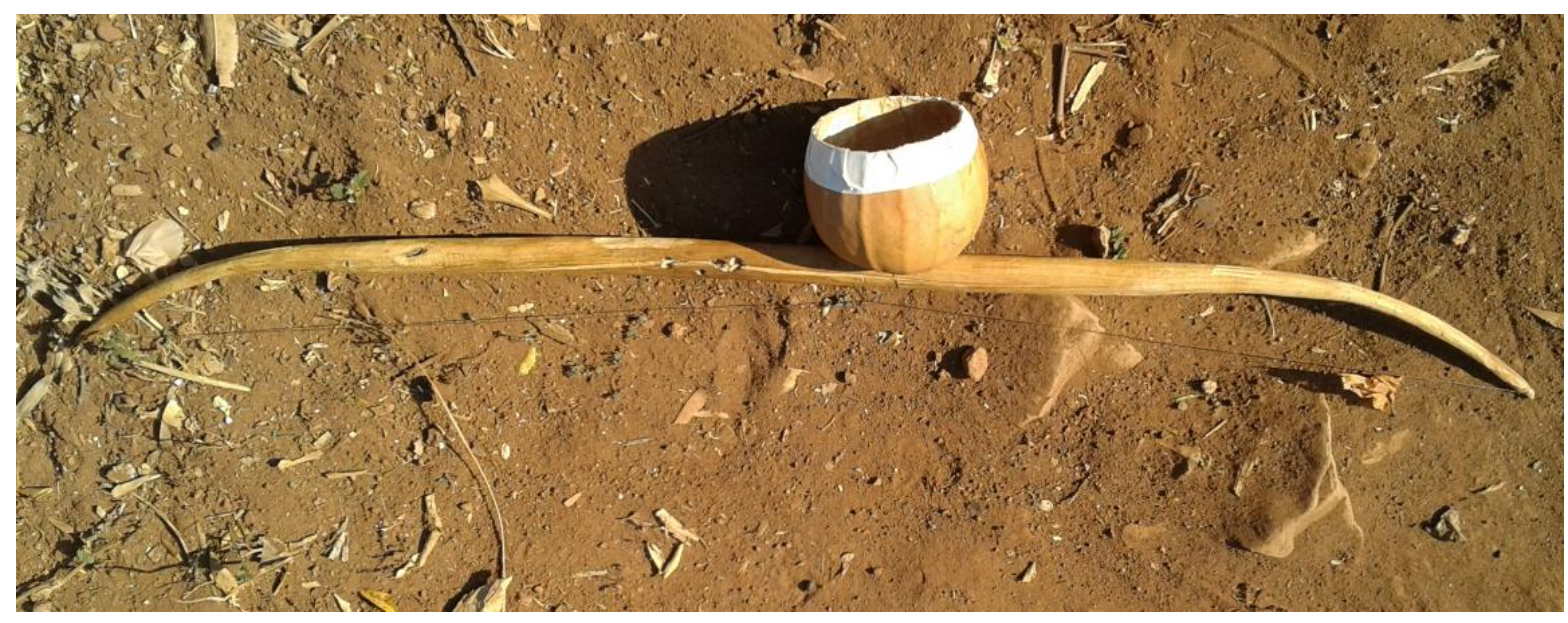

Figure 1.1 an example of a Dende instrument 2017

He used to walk through the streets playing the instrument to encourage music appreciation in the community. He was a man who stood firm against all odds as a traditional musician, pushing boundaries and breaking stereotypes. At the core of his mission was the spirit to fight for recognition in society. This man found an opportunity to make a little money by going from house to house, playing his instrument. He became a laughing stock to the children because no one understood the model he was trying to create; his enthusiasm also became a symbol of how unsuccessful a musician could be in a society. The money he made was not enough to sustain his lifeblood. On the positive side, he brought excitement to children, and ignited sparks of interest amongst them to follow music as a career. He was loved by the community and he initiated a model of solo performance appreciation against the odds (as most communities were used to communal music). The negative side of the story is that because he did not make a lot of money from playing his instrument, the community often saw him as a suffering musician. His low status as a struggling musician discouraged potential future musicians to follow him. His means of survival was tantamount to that of a beggar.

African indigenous music heritage can be separated into two categories - indigenous cultural dances and indigenous instrument specialization music. African indigenous cultural dances have the most distinctive elements of indigenous cultural music heritage and then followed by indigenous instrument specialist music. The indigenous cultural dances are often a group performance by a community of a traditional music rendition, while instrument specialist performances are a rendition by a solo artist of an indigenous music instrument. Both musical forms are classified as indigenous African cultural music heritage. Indigenous cultural identities may include things, such as music, instruments, cultural attire (costume), dance, food, language, etc. The indigenous cultural dances are the most distinctive because they encourage a social hegemony of a community and mass participation, which is a core function of African music performed by a community. Omofolabo Ajayi, in the studies of the Yoruba dance of the Nigerian people, explores the importance of the body as a traditional instrument to articulate semiotics of a culture at a different communication level. He argues that "dance conveys messages through the visual, aural, olfactory, tactile, proxemics, and kinesthetic channels," (Ajayi 1998: 22).

Cultural dance music often takes the shape of dance music because everyone is able to contribute to the enrichment of the music through dance. Main features of this kind of indigenous music may include, drums, hand-clapping, dancing and singing while wearing particular cultural attire (costume). Each dance also has a specific function; some general examples that dances are used for are celebrations, ceremonies and rituals. For these dances, a unique uniform is a requirement - it is also specific to each ethnic and cultural group. An example below is a demonstration of a dance from a tribe called the Venda people situated in the north of South African. 




Figure 1.2 an example of a cultural dance by a tshigombela dance group from Tshaulu village from Venda in Limpopo province in South African 2017

A community music performance has a higher status in a communal setting because it is also associated with performances that are performed in the presence of a king or a chief. These performances have to have a certain level of proficiency and dignity, as each performance carries certain messages that may be directed to the king for his attention. Performances have to have a certain level of respect depending on the kind of performance taking place. In Venda culture, for instance, a king can never address the crowd before the tshikona music is performed. This is a Venda cultural practice before the king speaks to the people. Tshikona music must be performed before the king stands up from his chair as a Venda cultural custom. This kind of music is also used for burial events when a royal member has passed on. Such indigenous music requires particular attention by the community, as it symbolises a cultural pride in the community through events that are associated with the king.

A solo or an ensemble rendition by indigenous instrument specialists of an indigenous music would include a performance with some virtuosic ability by the artist or artists playing a particular indigenous instrument. Such instruments vary from culture to culture, and they are played by few artists in many communities. Most of these artists are very scarce, and they are also very talented in many ways. They are able to understand intricate information about the instrument, such as the special turning of the instrument they play; they also have the ability to make or design the instrument themselves from scratch. They are also regarded as knowledge keepers in their communities, as they are teachers by default of the instrument they play. They are also very important in the community because they retain the educational aspect of teaching the instrument to others. The example below provides a picture of a female indigenous instrument specialist playing an instrument called Tshihwana. 


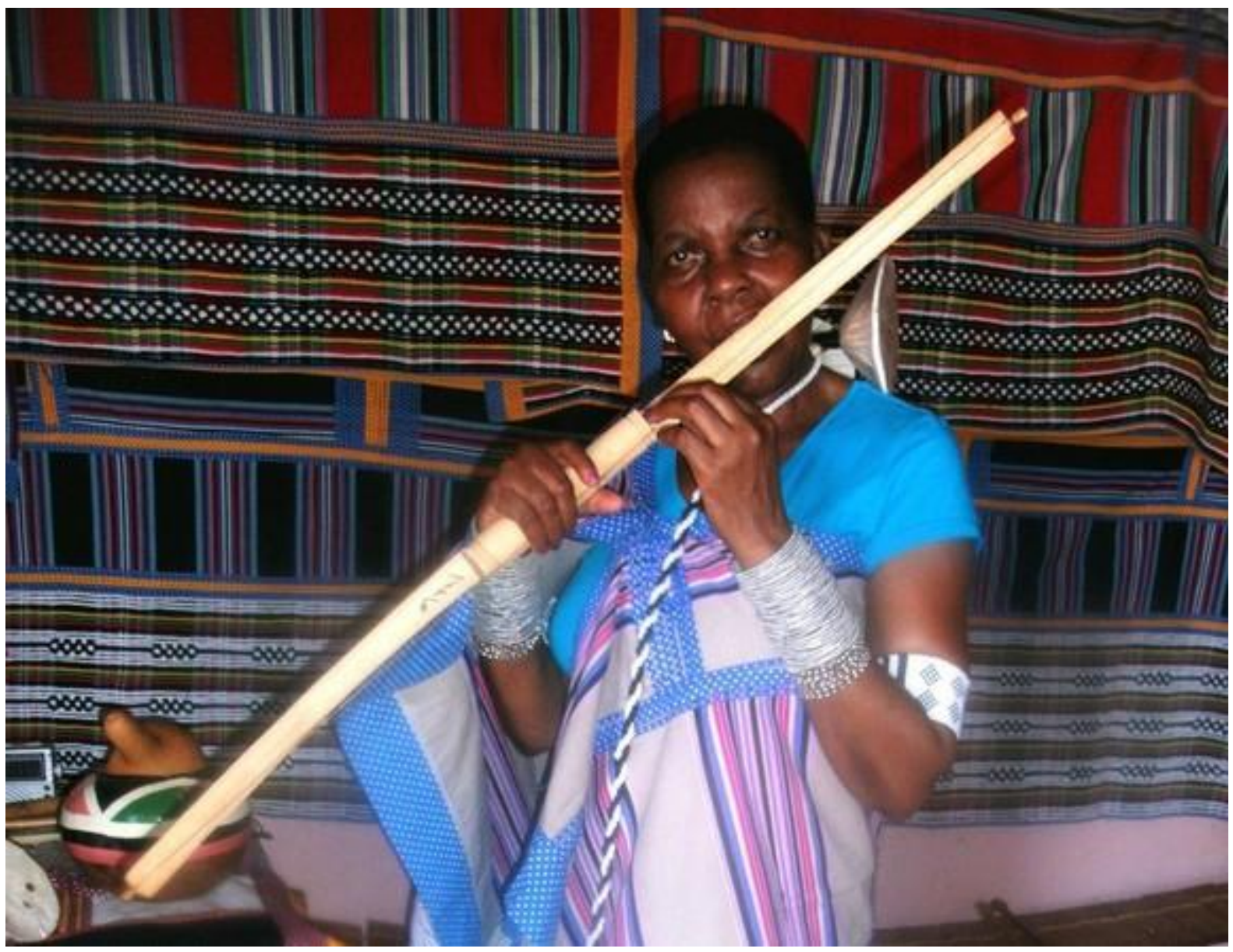

Figure 1.3 an example of an indigenous instrument specialist by Naledzani Netshirembe from Thohoyandou in Venda Limpopo Province in South Africa 2016 playing Tshihwana

There are very few of these artists in most communities and almost non-existent in others. They are generally traditional music composers in their own right, as they are able to create new music using their own instruments. The challenge with these musicians is other community members view them as special, talented artists, but on the other hand, from a community point of view, their knowledge is not seen as benefiting the community as it is considered self-centrered. The artists also do not benefit economically from playing the instrument because most music in a communal setting is shared music and not commercial music intended to make money.

Either of these two types of indigenous music practices can be used for different cultural performances, such as a king's event, ritual event, a celebratory event by the community, a specific ceremonial event, or personal events where people are able to pay the performers (such as weddings and graduations). This music is largely aural music without any form of documentation in the form of sheet music that can be printed and re-performed elsewhere by another person or group of people able to read music. The biggest challenge to perform such music, even if it is notated with standard sheet music notation (such as staff notation), is it would require particular instrumentation and understanding of how to turn such an instrument to maintain the indigenous characteristics of the music. Another challenge contributing to the threat to this musical heritage is that less and less it is being practised in the communities from which it originated. This is exacerbated by the fact that when the performers die with the knowledge they possess without passing it on to the next generation, usually because of the music generally not being notated or transcribed. This means most of the solo artists playing instruments, such as the Lugube, Tshizambi, Dende, Uhube (mouth bow), Tshitiringo (venda flute), Mbila dza mutondo (Marimba), Mbila or Mbira and others, are dying with their knowledge. 


\section{Direct factors that contribute in such music heritage not being documented as sheet music for educational purposes are as follows:}

There are several factors that have contributed to the disappearance of indigenous music heritage knowledge systems, and these are discussed in more detail below. Most of these factors, in turn, undermine the intelligence of African heritage knowledge, as they make it appear unimportant to preserve or promote. African musical heritage knowledge is not seen as current or relevant in contemporary society; as a result, there is a decline of such music taking centre stage in communities, as it previously did. Indigenous knowledge is always seen as a thing of the past. Indigenous cultural dances and instruments have been undermined.

\section{Extinction of indigenous heritage knowledge}

The African indigenous knowledge heritage is on the brink of cultural extinction. The methodology of oral knowledge preservation in Africa presents a challenge to the indigenous music heritage because it means that most of the existing knowledge is undocumented. The challenge often leads to the devaluation of African indigenous knowledge, the exclusion of African indigenous knowledge as part of education curricula, and less and less African indigenous knowledge being preserved and shared in the society. On the positive side, indigenous music heritage has a unique feature that gives it the survival edge it needs. This feature's scarcity is sometimes the reason researchers are attracted, and make the effort to go into the rural villages in the search for new knowledge to preserve and promote. In his article "Sacred Spaces and the search for Authenticity in the Kathmandu Valley”, included in the book, Historic Cities and Sacred Sites: Cultural roots for Urban Futures, Edward Sekler takes the identity of the culture further by indicating how a culture maintains itself and how it positions itself in a changing environment are essential for its survival. He argues that:

There are many ways in which a cultural identity is formed and maintained. Much of what happens in the process has to do with the intangible cultural heritage of a body of traditions and usage, rites, poetry, song, and dance. A great deal of all of this is passed on orally through generations. Consequently, its survival is always threatened (Edward F Sekler. 2001, 354).

The importance of maintaining the identity of a culture should be a priority in preserving indigenous knowledge heritage, as it plays a big role in the survival of the cultural heritage. Some governments have initiated revival projects in communities to try and keep the indigenous music heritage alive. Simultaneously, efforts initiated by African governments to foster a cultural revival at the national level to fight the decline of traditional dance at the level of the village community (Robert Nicholls 1996: 43, Ed, Welsh Asante).

\section{Religious change in society}

Many South African ethnic communities have been introduced to Christianity, which originally came to the country via missionaries. This religion has converted many people; as a result, the music they are encouraged to perform is music that does not have anything with ancestral worship or music with an indigenous spiritual connection. Indigenous music heritage was previously the biggest music performed by most of the communities at different ceremonial events, but this is no longer the case. Robert Nicholls, in his article "African Dance: Transition and Continuity" (which forms part of a book edited by Asante Welsh called African Dances (1996)), uses a Nigerian example where Christianity has also contributed to the extinction of traditional dance asa result of Christian churches not allowing the performance of traditional dances for fear that some dances are related to spiritualism, which could be considered contrary to Christian belief. He argues that "the effect of sociocultural change on traditional dance in Africa impacts in diverse areas. Christianity, for example, discourages traditional dance and has failed to acknowledge, with the exception of the Aladura-type (free churches in Nigeria), that dance in Africa is a means of expressing spirituality," (Robert Nicholls 1996: 41, Ed, Welsh Asante). Tracy Snipe, in the same book under his article "African Dance: Bridges to Humanity", echoes 
what Nicholls says about religion playing a role in giving African dance a different perspective or no perspective at all. It is evident in many African cultures that the extinction of certain dance practices is related to change in religion practice (particularly Christianity) or the adoption of a different faith thereof. Snipe also argues that some dances are seen as inappropriate for those who have now been converted to Christianity to practise, as they denote a different spiritual force that is against Christianity faith.

To convert the enslaved Africans to Christianity meant that they would have to be treated with some remnants of humanity, but Christianity forced Africans to deny many aspects of their heritage, such as polygamy, ancestor worship and dancing (Tracy Snipe 1996: 67, Ed, Welsh Asante).

Robert Nicholls takes this argument further to try give more flesh to the point that indigenous music heritage, particularly dance music, has been diminishing as music practised by African communities. He says that.

In Africa, the decline of traditional art means more than a loss of entertainment or a diminishing of aesthetic. Indigenous cultures are functional social instruments, which have been developed over the centuries to meet practical needs. In non-literate societies, art forms contain a mosaic of information and skills for coping with a variety of environments, many of which are extreme. They serve not so much as an artefact - an end in itself, but more as a process - a means to an end (Robert Nicholls 1996: 42, Ed, Welsh Asante).

\section{Lack of interest from the younger generations to learn indigenous knowledge}

Urbanisation has become one of the biggest threats to the extinction of arts and culture heritage knowledge in Africa, and South African in particular. Governments try put policies in place to save the arts from a complete death. In order to bridge the gap between culture and urbanisation, governments reinforce the revitalisation of indigenous cultural heritage events, by means of small grants funding communities that are reviving their cultures. Urbanisation however, requires one to be current, relevant and to fit into the structure of modern society. All these factors contribute to the threat of indigenous heritage knowledge extinction in society. The other challenge is that there is no interest from the youth to learn such instruments, which is distressing to most artists who play indigenous instruments, because they are unable to pass the knowledge to future generations. Parents do not encourage their children to study indigenous music because, according to them, music is not economically viable or it is not understood as something from which one can make a living. They see the artists who play these indigenous instruments as people who are suffering in the community and no one appreciates their music and talent. It is a little bit different when it comes to community music because in some villages it is mandatory for all young girls and boys to participate in indigenous music as part of their heritage initiation. This kind of initiation is believed to instill respect and discipline in young people and to also teach them to treat elderly people with respect. But, this practice is no longer mandatory in many modernised communities (apart from the rural communities that are still under the rulership of a king or a chief).

\section{Lack of indigenous knowledge recognition as part of an education curriculum}

The education system of the South African government does not take the arts seriously. The arts are seen as an extracurricular activity separate from the education syllabus. This then means that it is not mandatory for learners to be taught arts and culture. Music education is difficult to access by those who have an interest in studying it. Arts and culture education is a choice, not a compulsory subject. The situation makes arts and culture look like they are a thing for the rich, because only those who have money will be able to take their children to private schools to learn arts and culture as it is not offered in government schools. When a society is faced with challenges such as these, and the worst case scenario is to try rescue the situation, music activists take the initiative to rectify the problem by conducting field research. It is not easy to rectify because this must be a government responsibility to make sure that the education system recognises arts and culture heritage as part of the syllabus. The government is not trying to close the gap by making sure that it avails organisations of 
funds that bridge this cultural gap. We need dedicated musicologists who have a vested interest in documenting the arts and culture knowledge, particularly indigenous music heritage. Nicholls indicates that "educational processes are often faulted for making little reference to indigenous sociocultural ecology," (Robert Nicholls 1996: 42, Ed, Welsh Asante).

Education should be the driving force behind the promotion of indigenous cultural heritage knowledge, and this is achieved through formalising indigenous knowledge system as part of a basic education curriculum. Education system should be used as a vehicle to encourage communities to preserve their cultures. If such a model was adopted by the education system, all learners would be able to participate in such activities. Education is the best tool to impart cultural heritage knowledge to coming generations. The Department of Basic Education (DBE) in South Africa does not include musical education as a mandatory subject in government schools and the Department is failing to incorporate indigenous knowledge systems as part of foundation phase education. I believe this is the level at which learners should be introduced to the importance of indigenous cultural heritage. We cannot expect our learners to foster an interest in indigenous knowledge unless we train them in the knowledge while they are still young. It is unfair to expect learners to start learning about and researching their indigenous musical heritage at a postgraduate level when it was never part of their lives previously.

Due to this knowledge gap the Department is failing to close, many researchers from other countries (particularly from West Africa) have taken advantage of this gap by studying the indigenous music of African cultures. Their initiative has made many African scholars feel guilty and jealous of failing to take the documentation of their own music seriously. The amazing thing about many of these scholars is that they have acquired their knowledge overseas, in foreign countries. They have then realised that other countries are hungry for more knowledge about African indigenous music heritage. The challenge is that there is not enough written about it by African scholars who know and understand the music better. Most of what has been written has been done by European or Western researchers who are often criticised by other researchers for having a biased, Eurocentric approach to studying African music. The criticisms have emphasized the need for a more ethical approach to the African music by such researchers and how they represent African music in the global arena. Some of these criticisms were motivated by reasons, such as an identity of a particular culture studied often but not well represented without the cultural dignity properly maintained. Tracy Snipes, in her article "African Dance: Bridges to Humanity", in the book African Dance, 1996 edited by Asante Welsh, explains that "though African dance have to be abridged when they are performed on the stage, the integrity and essence of the dances must be maintained" (Tracy Snipe 1996: 73, Ed, Welsh Asante).

\section{Most indigenous African music heritage does not exist as documented sheet music}

African indigenous music heritage as sheet music is one of the biggest problems amongst all the art disciplines that are under-documented. There is not enough done to document African indigenous sheet music. We need a multitude of scholars who will rise to the challenge of documenting and transcribing indigenous music heritage. This can inform policy change in government and can also be used as a model of training indigenous musical education in schools. It is not easy to influence policy change as there are many challenges and steps that are taken leading up to an inclusion of a new policy. However, theorists and musicologists, together with musicians, can create a model that government can adopt as a policy model. There are many organisations that are already doing a lot of work that government should be doing, such as offering music education to schools. The challenge is that most of these organisations are not offering indigenous music education. These organisations do not want to sit down and just wait for the government to bring about change. They became the change that society needed to recognise indigenous music heritage as a viable educational subject. To sit and do nothing while complaining and blaming government does not help to develop the arts and cultural heritage; in fact, it damages it even further. 


\section{Poverty leads to decline of cultural performances in communities}

It is not possible for one to dance on an empty stomach. People would rather go to industrialised cities to search for jobs rather than waste their time performing indigenous music, which does not put bread on the table. Hunger takes the joy of performing away, and the interest of protecting and preserving the culture disappears because people must eat. In most traditions, there is the saying "Muzika a u liwi", which essentially means you cannot eat music. This is because such indigenous music is seen as not economical for providing food for the artist. Most cultural events that are initiated by a king would have an abundance of food for everyone to eat, as the king will kill enough cattle to feed his people. However, this is just food for one day, because after the event those who do not work will be in the same situation they were before the event, so they have to look for paying jobs to feed their families. This is where Robert Nicholls uses poverty as one of the contributors to indigenous cultural music heritage declining in communities. He argues that "impoverishment in many rural areas in Africa can be directly attributed to the decline of the traditional culture, of which music and dance is an integral part (Robert Nicholls 1996: 42, Ed, Welsh Asante). Many communities are motivated to continue practising their indigenous musical heritage because they want to maintain their cultural identity. Nicholls says that "due in part to a nostalgia for a classical past, but primarily to develop a national sense of cultural identity, many countries have sought to showcase their traditional dances, (Robert Nicholls 1996: 43, Ed, Welsh Asante).

\section{Modernisation and urbanisation in society}

Living in changing societies where indigenous communities become modernised towns and cities, with better access to better infrastructure and services such as roads, hospitals, schools, etc. societies have to adapt to new changes, which also affect the practice of indigenous musical heritage. Robert Nicholls looks at a society as a living entity that uses human existence for its life-cycle transitions of a sociocultural rite of passage. The cultural paradigm shift of adapting to the new lifestyle in a society, presents a challenge to the practice of indigenous musical heritage. He argues that:

The evidence shows, however, that modernity is having an adverse effect on traditional dance. Critical social changes are leading to the demise of many traditional customs, which endangers dance. Oral traditions are fragile, and experiences, insight, and methodology that have sustained African communities for generations could well be lost to future generations (Robert Nicholls 1996: 41, Ed, Welsh Asante).

It is inevitable for cultures to be absorbed into modernity as cultures are slowly converted into urban settlements as a result of popular demand. Rural cultures become more and more modernised into urban developments. Robert Nicholls attributes some of the challenges that indigenous musical heritage has faced due to urbanisation in societies. He argues that:

The mass media are narrowly based, has a large percentage of foreign program content, [which] promotes an urban bias, and [is] insensitive to the different needs and cultural particulars of rural dwellers. Moreover, interaction with pop culture by the young has created a generation gap. For the adult population also, aspects of consumerism have proved a potent lure, stifling participation in the African cultural milieu, especially among modernised urban dwellers (Robert Nicholls 1996: 42, Ed, Welsh Asante).

The cumulative impact of various modernising agencies, such as education, mass media and urbanization, has eroded the indigenous culture, and tradition makes little impact on modern priorities (Robert Nicholls 1996: 41, Ed, Welsh Asante). 


\section{Conclusion}

\section{One of the solutions to creating an African sheet music repository may be the use existing archival structures} to promote indigenous sheet music in South Africa

An independent archive institution, such as the South African Music Rights Organisation (SAMRO) archive is the best platform to preserve and promote sheet music for public consumption. The SAMRO archive holds one of the biggest collections of sheet music of different composers in southern Africa. The collection includes some of the older handwritten scores and digital scores of original classical or jazz works, orchestra arrangements, or arrangements of original works. There are also university archives that primarily preserve and promote educational books that have sheet transcriptions, but the challenge with these archives is that they are accessible to students and academic lecturers but not to the public. They also do not have collections of indigenous sheet music other than the transcriptions that are in books. It is also worth noting that there are, however, many ethnomusicologists who have attempted to transcribe the indigenous South African music of different cultures. The only problem with most of their transcriptions is that they are not preserved in a sheet music format, but rather as part of a book. Most transcriptions done by ethnomusicologists are part of their publications, used as evidence to support their research. This is problematic for people who want transcription as separate sheet music to perform, as it is very difficult to search for books with such indigenous transcriptions about South African musical heritage. It is important to have a one-stop-shop to access indigenous sheet music transcriptions of South African musical heritage.

\section{Some of the initiatives that can help to combat this problem are as follows:}

For indigenous music heritage to survive against all these odds the following suggestions can be implemented for preservation and educational purpose

- Transcribing indigenous music as sheet music, live recordings, interviews etc. thereby giving it the same respect as western art music

- Using existing models that are created by non-profit organisations to lobby for policy change in the education sector

- Lobby for indigenous music heritage to be included as part of the education system

- Using existing public music archives such as SAMRO, ILAM and DOMUS to promote indigenous sheet music

- Encourage institutions of higher learning to make research transcriptions available to public archives

- Encourage researchers to also make their indigenous music transcriptions available not only as part of a research book but as standalone sheet music publication

\section{Acknowledgements}

I would personally like to thank my family for the support they gave me while doing this research. My appreciation also goes to the community of the Venda people in the north side of South Africa who have given me an opportunity to learn about their cultural music.

\section{References}

Agawu, Kofi. 2006. "Structural Analysis or Cultural Analysis? Competing Perspectives on the 'Standard Pattern' of West Africa Rhythm”. Journal of the American Musicological Society, 59(1): pp. 1-46. California Press, United States of America. 
Agawu, Kofi. 1995. "The Invention of African Rhythm”. Journal of the American Musicological Society, XLV III (3), pp. 380-395. California Press, United States of America.

Agawu, Kofi. 2003. Representing African Music. Taylor \& Francis Books, Inc. United States of America.

Arom Simha.1991. Africa Polyphony and Polyrhythm: Musical structures and Methodology. Cambridge University Press, United States of America.

Berliner, F. Paul. 1993. "The Soul of Mbira". Music and Traditions of the Shona People of Zimbabwe. United States of America, University of Chicago Press, Ltd, United States of America.

Blacking, John. 1967. Venda Children's Songs. Witwatersrand University Press, Johannesburg.

Blacking, John. 1973. How Musical Is Man? University of Washington Press. Seattle.

Blacking, John. Music, Culture, and Experience: Selected Pater of John Blacking. Edited by Reginald Byron. University of Chicago Press. London .

Blacking, John and Joann W. Kealiinohomoku, eds. 1979. The Performing Arts. Mouton Publishers. New York.

Cooper, Grosvenor and Meyer, B. Leonard B. 1960. The Rhythmic Structure of Music. University of Chicago Press, Ltd, United States of America.

Nicholas, N. Kofie. 1994. Contemporary African Music in World Perspectives. Ghana University Press. Accra.

Nicholls, W. Robert. 1996. Transition and Continuity. In: African Dance: An Artistic, Historical and Philosophical Inquiry, edited by Welsh, K. Asante. Canada. Africa World Press, Inc. Canada. pp. 41-62.

Snipe, D. Tracy. 1996. Bridges to Humanity: In: African Dance: An Artistic, Historical and Philosophical Inquiry. Canada, edited by Welsh, K. Asante. Africa World Press, Inc. Canada. pp. 63-78. 